\title{
Migrants as Transnational Development Agents: An Inquiry into the Newest Round of the Migration-Development Nexus
}

Thomas Faist*

Department of Sociology, Center on Migration, Citizenship and Development (COMCAD), Bielefeld University, D-33501 Bielefeld, Germany

\section{ABSTRACT}

Migrant networks and organisations have emerged as development agents. They interact with state institutions in flows of financial remittances, knowledge, and political ideas. In the discursive dimension, the new enthusiasm on the part of OECD states and international organisations, such as the World Bank, for migrant remittances, migrant associations and their role in development, is a sign of two trends which have coincided. Firstly, community as a principle of development has come to supplement principles of social order such as the market and the state. Secondly, in the current round of the migrationdevelopment nexus, migrants in general and transnational collective actors in particular have been constituted by states and international organisations as a significant agent. In the institutional dimension, agents such as hometown associations, networks of businesspersons, epistemic networks and political diasporas have emerged as collective actors. These formations are not unitary actors, and they are frequently in conflict with states and communities of origin. The analysis concludes with reflections of how national

* Correspondence to: T. Faist, Department of Sociology, Center on Migration, Citizenship and Development (COMCAD), Bielefeld University, D-33501 Bielefeld, Germany. E-mail: thomas.faist@uni-bielefeld.de states structure the transnational spaces in which non-state actors are engaged in crossborder flows, leading towards a tight linkage between migration control, immigrant incorporation and development cooperation. Copyright @ 2007 John Wiley \& Sons, Ltd.

Received 11 May 2007; revised 19 July 2007; accepted 24 July 2007

Keywords: transnational migration; transnationalism; development; migrant associations; community

\section{INTRODUCTION}

7 he new enthusiasm, sometimes described as the 'new mantra' (Kapur, 2004), around migration $^{1}$ and development hinges on a number of strong claims. They can be summarised in the statement that the flows of money, knowledge and universal ideas - called remittances - can have a positive effect on what is called development in the countries of emigration. The first claim is that financial remittances carry a huge potential for poverty reduction and local investment, especially since remittances very often are resistant or even counter-cyclic to economic recession. The amount of remittances transferred to developing countries flowing through officially sanctioned channels such as banks or money transfer services are estimated to have increased sharply over recent years - at 
$\$ 167$ billion for 2005, up from about $\$ 40$ billion in 1990 (International Organisation of Migration, 2005: 270). This is at least double the sum of the OECD's annual Overseas Development Assistance (ODA) budget. ${ }^{2}$ Secondly, despite the fact that financial remittances still stand at the core, in this new round of enthusiasm, more emphasis is placed on the transfer of human capital from North to South. Now the perceptions of costs and benefits have changed with shifts in ideas, from 'brain drain' in the 1970s to 'brain gain' in the 1990s. Nowadays, we supposedly find more winwin situations for mobile persons, states and others involved (Findlay, 2003). And even newer is the concept of 'social remittances' (Levitt and Nyberg-Sørensen, 2004), the flow of ideas and practices which are 'good' and to which nobody in his or her right moral mind would object: human rights, gender equity and democracy, to name only the most obvious ones. Occasionally, diasporas made up of exiles, refugees and labour migrants are hailed as mediators in conflict resolution, for example in the cases of South Africa or Nigeria (Shain and Barth, 2003). Thirdly, part of the mantra - it has to be repeated a lot to be believed - is the desirability of temporary labour migration because of the hope that temporary migrants transmit a higher percentage of their income than permanent immigrants, and the belief in circulation of ideas and knowledge, which is connected to short-term visits of migrants as development agents. Policy-wise, this view has especially been propounded by Kofi Anan's Global Commission on International Migration (GCIM, 2005), which was given visibility by the UN High Level Dialogue on Migration and Development in 2006. Overall, these three broad optimistic claims are tied to migration control. It is the hope expressed by political institutions such as the EU Commission that, in the long run, economic growth supported by financial, knowledge and social remittances will reduce 'migration pressure' in the sending countries (European Commission, 2005). In all of this, transnational ${ }^{3}$ networks and associations of migrants have come to stand at the centre of the optimistic visions of national and international economic development policy establishments.

The positive role attributed to migrants and their collectives for development may come as a surprise. After all, transnational migration was considered a sign of development failure during much of the 1970s and 1980s. It can be conceptualised as a territorial or geographical exit upon failure of the state or other institutions to deliver well-being and human security (Hirschman, 1970). Since the 1990s, however, international organisations led by the World Bank, non-governmental organisations (NGOs), and OECD nation-state governments have increasingly touted remittances as a solution to development. We have witnessed in the past decades a slow but steady increase in the proportion of transnational migrants as a percentage of the world population from 1 to $2 \%$ in the 1960 s to about $3 \%$ in the current period, despite the fact that the overwhelming part of the world's population is characterised by 'relative contingent fixity'; that is, do not migrate across state borders (Clarke, 2004: 418). One of the expected consequences of this increase is that there should be a greater potential for transnational flows such as remittances. While the assumptions underlying the developmental effects of remittances are heavily contested (de Haan, 2006), the focus here is different: not the impact on development as such, but the role of migrants and their associations as transnational subjects. In particular, collective actors such as village and hometown associations have come to occupy the imagination of both academic analysts and policy-makers (Merz et al., 2007).

The argument put forward is two-fold. As to the discursive dimension, the new enthusiasm on the part of OECD states and international organisations such as the World Bank towards the crucial role of migrant networks and associations in furthering economic, scientific and political development in developing and transformation countries is a sign of two trends which have coincided. 'Community' and, often used interchangeably, 'civil society' as a principle of development has come to supplement principles of social order such as the market and the state. Also, in the current round of the migration-development nexus, migrants in general and transnational migrant associations in particular have emerged as significant agents. In an institutional dimension, agents such as hometown associations, networks of businesspersons, epistemic networks and political diasporas are portrayed as unitary collective actors.

This empirical analysis uses a transnational approach in order to capture this recent pattern adequately. Transnational analysis involves 
studying the ties that cross emigration and immigration states, sending and receiving regions. Transnational social spaces consist of combinations of social and symbolic ties and their contents, positions in networks and organisations, and networks of organisations that cut across the borders of at least two national states. In other words, the term refers to sustained and continuous pluri-local transactions crossing state borders. The smallest element of transnational social formations is transactions, bounded communications between at least three persons. More aggregated levels encompass groups, households, organisations and firms (Faist, 2000: 278). Even higher is the societal level, namely as crossborder societal systems which may reach up to emergent structures of a world society looming on the horizon.

The analysis proceeds in two steps. Firstly, in the discursive dimension, the analysis poses the questions of how academic and policy thinking on 'development' has cast the role of communities and non-state organisations in the past few decades, and how migrant collectives have emerged as transnational agents in the current round of the development nexus. Secondly, in the institutional dimension the analysis probes the ways through which the activities of transnational cliques, groups and organisations have been engaged in what is called development. Indeed, little is actually understood about the role that transnational groups and organisations play vis-à-vis states and other agents when it comes to the transfer of financial capital such as remittances and investments, knowledge and political ideas. The third section of this analysis touches on the implications for further research and argues that transnational social spaces indeed constitute social formations sui generis. Nonetheless, it is states which structure the triangle of migration control, immigrant incorporation and development cooperation.

\section{THE DISCURSIVE DIMENSION: DEVELOPMENT, MIGRATION, COMMUNITY AND CIVIL SOCIETY}

The trends in development theory in general and in reflections on the two-way linkage between migration and development have coincided. In development theory the principles of 'community' and 'civil society' have occupied an

Copyright (c) 2007 John Wiley \& Sons, Ltd. increasingly prominent role over the past few decades, without necessarily displacing the 'state' and certainly not the 'market'. Migrant transnational associations constitute the newest expression of this trend, as evidenced by the evolution of the migration-development nexus.

\section{Development Theory: From State to Market and to Community and Civil Society}

Heuristically, one may distinguish three principles of social order - community, state and market. Here, the community principle refers to the notion that social order presupposes, or at least benefits from, the rights and duties that are attached to members of collectives of persons. Communities constitute the cement that integrates the members of concrete communities into values of trust, reciprocity and solidarity, bounded by rights and obligations of members towards each other. Rights and duties delimit the boundaries of communities, which may rest on diverse mechanisms such as kinship lineage, shared knowledge and values, belief in common institutions or religious beliefs. The boundaries of the market are quite different in that dispersed competition is ideally driven by the interest of human agents in the purposive acquisition of individual goods, without much or indeed any consideration of, or control over, what impact the pursuit of acquisitive purposes may have on others or on other peoples' future selves. The principle of state consists of hierarchical control, carrying binding decisions in political communities. State authority is meant to serve the common good, in the case under consideration here culminating in the notion of development. Whereas communities are characterised by various notions of boundaries of 'us' distinct from 'others', and markets exist without geographical borders, states - at any rate in their modern incarnations since the Westphalian Peace - are defined both by clear territorial borders and boundaries set by their function to implement authoritatively binding decisions by the force of power and legitimacy. In short, community, market and state are master mechanisms of social order characterised by incompatibilities, yet also requiring one another for their function (Streeck and Schmitter, 1985).

Discursively, the importance of community as a pillar of development has increased over 
the past three decades. The more recent focus of development policy on transnational subjects in the context of increasing remittances of migrants fits with a context in which the role of the state and the market have been fundamentally reevaluated by international development organisations. Bringing 'community' back into thinking on development policy can be seen as an incremental process which has occurred over roughly four successive phases.

\section{Phase 1: The Developmental State}

The first phase refers to the long period after the Second World War in which development such as import substitution industrialisation occurred under mainly state-led industrialisation. Corresponding academic theories, such as modernisation theory of the 1950s and 1960s, did not attribute a crucial active role to (small) groups and organisations, other than as recipients of massive cultural, political and economic change (e.g. Huntington, 1966).

\section{Phase 2: The State and Basic Needs}

This state of affairs began to change, making a second phase, launched by the World Bank's 1973 call for targeting development efforts to the 'poorest of the poor'. This proclamation catalysed a shift in focus away from growth and towards issues of redistribution and equity. Understandably, this ideational move involved an increasing emphasis on community participation in development. Whether labelled 'farmer-first', 'bottomup' or 'grassroots' development strategies, the focus was on decentralisation, localisation, and the satisfaction of basic human needs for food, shelter, health, and what we nowadays call human security.

\section{Phase 3: Neo-liberal Strategies}

The foregrounding of community coincided with increasing criticism of the 'developmental' state and, above all, an attendant greater role of market principles in the 1980s. Organisations like the World Bank called for greater participation in the world market (McMichael, 1996: 111), in marked contrast to policies inspired by dependency theory which advocated a partial dissociation from world market participation. Influenced by events of the 1970s and 1980s, such as the debt crisis in Latin America and the implosion of postcolonial states in parts of Africa and elsewhere, academic studies also emphasised the economic distortions effected by rent-seeking elites in command of predatory states (Bates, 1988). International development institutions began to place more faith in the operation of more-or-less unfettered markets, and in the benefits of marketdriven growth as promising for societies whose potential for economic growth had been stymied by what were considered inefficient state institutions. A shorthand description of this trend was the 'Washington Consensus'. Indeed, international organisations such as the International Monetary Fund (IMF) pressured recipient governments to rely on price signals and little else for social coordination, thus advocating privatisation, deregulation, and the demolition of labour rights and social subsidies (Chang and Grabel, 2004). In crafting policy, international development agencies increasingly bypassed developing country governments, choosing instead to rely instead on the mediation of international and local non-governmental agencies.

Phase 4: The Market, the Community and

Civil Society

Since the mid-1990s, the trend toward marketisation coincided, perhaps awkwardly but certainly not incidentally, with an anti-étatist notion that development entailed the empowerment of communities and individuals themselves to undertake the 'development project'. Obviously, the emphasis on local autonomy and grassroots participation was meant to provide a useful corrective to top-down development strategies of the past. In policy thinking, in short, the state was retreating as a mechanism for creating social order and the community emerged as a compensating mechanism. In a paradigmatic conceptual innovation, the international development policy agencies began to use new concepts presumed to drive development - the concept of 'social capital $^{4}$ being one of the most important (Evans, 1996). Conceptually, the notion of social capital hints at the marriage of the market and community principles. Resources inherent in social ties - such as reciprocity and solidarity - are thought to constitute capital which yields interest; for example, access to financial and other social resources. Major actors in development policy such as the World Bank and a myriad of NGOs propagated more participatory forms of development at the local level. Ideas of globalisation 
'from below' have logically focused on diasporas and transnational communities. In this process, the role of the state as a principle of social order in development has changed as well. It is now a service provider for markets and partly for communities, creating the very conditions for market exchange through non-corrupt rule-making, a stable bureaucracy, and the guarantee of minimum human, civil, and political rights. In a nutshell, political and legal structures provide the necessary infrastructure for economic growth (cf. North, 1990). Notions such as 'good governance' and establishing the 'rule of law' in the aftermath of the 'third wave of democratization' (Diamond, 1996) rule supreme in the universe of developmental concepts.

\section{The Migration-Development Nexus: Migrants as Transnational Development Agents}

Thus, there has indeed been an ideational change in bringing community back into the development discourse and, most recently, transnational groups and organisations. While it extends to a larger universe of human rights or gender equity associations, it can also be seen in the realm of the migration and development discourse. Yet it is important to remember that it is not the first time since the Second World War that the relationship between migration and development the migration-development nexus - has entered the political discourse, although it is now the first time that 'community', in addition to general references to migrants as such, has come to play a prominent role. Aspects of migration and phenomena which after the late 1940s have been called 'development' figured much earlier than the 1960s. In their seminal work on The Polish Peasant in Europe and America (1927) William Thomas and Florian Znaniecki spoke in detail about 'the role of supra-territorial organisations'. Thomas and Znaniecki began their analysis with the attempts of Polish-American priests to bring together the representatives of the Polish colonies in America (Polonia Americana) and manage the common affairs of the American Poles, and then went on to discuss the role of Catholic, nationalist, socialist and humanitarian organisations in structuring both adaptation in the US and what later would be called modernisation in Poland. However, the term 'development' was not connected to migration in academic and public discourses in explicit ways until the 1960s. It is interesting, yet not surprising, that the conceptualisation of the nexus between migration and development mirrors the dominant economic development paradigms, economics being the leading and most conspicuous discipline in conceptualising development. The following three phases of the nexus can be distinguished:

Phase 1: Migration and Development - Remittances and Return

During the 1960s public policy emphasised the 'labour gaps' in the North and 'development' in the South. The latter was supposed to result from financial remittances, return migration and the subsequent transfer of human capital (Kindleberger, 1967). This view clearly corresponded to overall economic modernisation concepts and to a belief that state capacity could shape economic growth. Moreover, it was congruent with the economic textbook mantra which suggests that emigration of surplus labour from underdeveloped areas leads to a new equilibrium between capital and labour (Lewis, 1954): if labour goes North, labour scarcities in the South then create an inflow of capital - and eventually economic development in the South (cf. Hamilton and Whaley, 1984). ${ }^{4}$

\section{Phase 2: Underdevelopment and Migration - Poverty and Brain Drain}

During much of the 1970s and 1980s the term development came to be replaced by 'dependency' as a structural condition of the periphery dominated by a centre, and 'underdevelopment' as its inevitable result. During this period, in which dependency theory and later world systems theory à la Immanuel Wallerstein (Wallerstein, 1974) criticised modernisation theory, the nexus was partly seen the other way around in terms of assumed causality, not from migration to development but from underdevelopment to migration (for an example, see Portes and Walton, 1981). In terms of public policy, one of the central issues was not financial remittances - remember that most European countries stopped recruitment, closed their main gates and kept only side doors open for selected categories in the 1970s and 1980s - but the issue of 'brain drain'. In a dependency perspective, underdevelopment led to the loss of the highly-skilled who migrated from the periphery to the centres in the 
dependent world, and above all into industrialised countries. This out-migration, in turn, was thought to contribute to even more underdevelopment and increased migration flows through asymmetric distribution of benefits and resources (Martin, 1991; Delgado and Covarrubias, 2005). This called into question the belief that the loss of the South's resources would be compensated for by reverse flows from North to South, called remittances. Evidence for this critical view is now easy to spot. For example, in 2005, between a third and a half of the so-called developing world's science and technology personnel lived in OECD countries. And it is almost unnecessary to note that a differentiated view of the movement of brains has produced 'brain strain hotspots' (Lowell et al., 2004), such as the healthcare sector in sub-Saharan Africa. This experience stands in stark contrast to that of countries (such as Taiwan, South Korea and the People's Republic of China) whose very rapid economic development could change the situation into a 'reverse brain drain' (Zweig, 2006).

Phase 3: Migration and Co-development - The Celebration of Circulation

Since the 1990s, the idea of what in French has been called co-développement (Naïr, 1997) best describes the public policy approaches of immigration countries to the migration-development nexus, at least those propagated by several states such as France, the Netherlands, the UK, and international organisations such as the World Bank. It is a reversal of the nexus and has led us back to a more optimistic view, akin to the 1960s. International migration is supposed to fuel development in South and East - the 'Global South' this time not only via financial remittances and human capital, but knowledge flows more generally and social remittances (Maimbo and Ratha, 2005). There seems to be a belief that more circulation of labour ${ }^{5}$ fosters more development by way of remittances and through knowledge networks. New issues come up, such as formalising the migration-development nexus by strengthening remittance channels through involving banks, and diaspora knowledge networks, which are not built upon the 'return option' but the 'diaspora option'.

In sum, currently, in both the general development paradigm in its focus on community and civil society, and the specific migration- development nexus with its renewed emphasis on migrant remittances, discursive opportunities have opened up and have spurred public policymakers to think about the potential significance of migrants as collective agents of change. It is therefore necessary to look more closely at what role migrant associations have actually played in selected areas, and how they have constituted a significant part of transnational social spaces.

\section{THE INSTITUTIONAL DIMENSION: TRANSNATIONAL SOCIAL SPACES AND MIGRANTS AS TRANSNATIONAL AGENTS}

While in phase 1 of the migration-development nexus policymakers and analysts only thought of remittances and return migration as a way of transferring resources across borders, in the third period the landscape of alternatives has widened in an era called globalisation, network society, or world society - an era of ever-increasing circulation. All of the new terms such as co-development point to the emergence of new transnational agents, that is, 'diasporic' actors (for a critique of the term diaspora, see Brubaker, 2005). Underlying this semantic change is the hunch that migrants, geographically mobile persons and those with whom they associate may be engaged in sustained and continuous cross-border practices. So the story is not simply about migration and development, but about transnationalisation.

Various agents have repositioned themselves locally in the global changes that have taken place over the recent decades. Both public policies and rhetoric have changed. A prominent example of the transformed political semantics is the discursive and institutional changes the People's Republic of China has implemented. Discursively, the previous motto of 'return to serve' (huiguo fuwu) has been replaced by the slogan 'serve the country' (wei guo fuwu) (Cheng $\mathrm{Xi}$ in Nyíri, 2001: 637). Such rhetoric has been complemented by public policy changes. Again, examples are easy to spot, including adaptations through mechanisms such as dual citizenship for emigrants and immigrants (Faist and Kivisto, 2007), voting rights for absentees, tax incentives for citizens abroad, and co-option of migrant organisations by local, regional and state governments for development cooperation. Instead of 
permanent return migration, temporary returns, visits and other forms of transactions have moved to the centre of attention. Thus, in recent years the notion of migrants' return as an asset of development has been complemented by the idea that even if there is no final return, the commitment of migrants living abroad could be tapped, not only, for example, through hometown associations but also through informal 'diaspora knowledge networks' (Barré et al., 2003), such as networks of scientists and R\&D personnel, business networks and networks of professionals working for multinational companies (Kuznetsov, 2006). States, development agencies and international organisations try to support the circulatory mobility of persons engaged. The key phrase is 'temporary return': an example is the International Organisation on Migration's (IOM) Migration and Development in Africa (MIDA) programme, which sends migrants as experts back to countries of origin for short periods of time. And, of course, governments try to tap into the activities of hometown associations, although - seen only in terms of financial remittances - it is a small fraction compared with remittances within kinship groups. A prominent example is the Mexican tres-por-uno (3 $\times 1$ ) programme, in which each 'migradollar' sent by migrants from abroad is complemented by three dollars from various governmental levels. More recently, banks have joined the fray and announced $4 \times 1$ programmes. The examples given suggest that states and organisations have started to build programmes around the obligations and commitments felt by migrants towards home institutions.

Analysing the role of transnational subjects within the new discursive and institutional frameworks requires a transnational approach to mobility which goes beyond the traditional binary concept. The conventional binary concept emphasises emigration from and immigration to particular countries, with possible re-migration to the countries of origin. By contrast, transnational migration and mobility should be understood as manifold processes linking together countries of origin, destination, and onward migration. The focus should be not only on migrants who settle for a meaningful period of time abroad, but also on those persons who engage in short-term mobility. Such social spaces are characterised by dense and continuous

Copyright (c) 2007 John Wiley \& Sons, Ltd. transactions across borders because, irrespective of where they settle, persons may entertain transnational ties that have impacts for the respective countries. Examples of social spaces formed by migrants and mobile people are transnational families, hometown associations, epistemic communities of experts and scientists, cross-border religious congregations, as well as ethnic and even national communities. ${ }^{6}$ This goes well beyond simply considering the category of former transnational migrants who eventually settle in the North, return to the original country, or engage in onward migration. The following analysis focuses on various transnational subjects, that is village groups, business networks, epistemic communities and diasporas. Such transnational social formations mobilise very diverse forms of resources in the name of deveopment: financial capital such as money in the form of remittances and/or investments; knowledge and professional experience; and political ideas, such as ideas on forms of government, rights and responsibilities, and democracy.

The notion of development is understood here in the way that it is used by different kinds of transnational communities: in the case of village communities as the improvement of the infrastructure and the provision of local collective goods such as education and health; in the case of networks of businesspersons as opportunities for investment and optimal interest; in the case of epistemic communities the unhindered flow of knowledge; and in the case of national communities a high degree of political autonomy, sometimes even involving the formation of an independent nation-state. All of these notions resemble the overall lowest common denominator which the term development has carried since the late 1940s, namely the vague hope of progression and betterment for those parts of the world deemed 'underdeveloped' (for a trenchant critique, see Escobar, 1995). A transnational approach means looking not only at developing countries and countries in transformation, but also at highly industrialised countries. In the latter case, there is value added in, for example, the contributions of migrants to social insurance and welfare state provisions, the closing of labour market gaps in the informal service economy, and the meta-norms of democracy and human rights transported by selected migrant categories. 
Village and Hometown Associations: Remittances and Conflicts of Interests with Communities of Origin

A perspective on village communities makes transnational transactions for the most part translocal, that is, local-to-local relationships across state borders. Examples are numerous, and village communities come in diverse shapes, such as home-town associations in the case of Mexico and Kamerun, returnee associations in Jamaica, or charitable foundations in Egypt (e.g. Lacroix, 2003). ${ }^{7}$ Such associations provide significant resources for community development at the local level by, for example, involving themselves in providing construction materials for their home-town church, raising money to improve water and sewage systems or health and education services, helping to organise relief efforts following natural disasters, or channelling remittances, especially in the Americas. We are dealing here with instances of focused solidarity, and - in case the individuals involved are anonymous to each other - diffuse solidarity.

While traditional emigration countries, such as Italy, have long had policies and programmes for (former) citizens living overseas, it is only relatively recently that emigration states have reshaped their relationship to hometown associations, often in a reactive way (Goldring, 2002, on Mexico). An even newer phenomenon is the interest shown by international organisations in the possibility that transplanted village communities could be useful in more than the maintenance of culture (Moja, 2005) but might also play a significant role in the economic development strategy of the emigration country. Some hometown associations and states cooperate in improving the infrastructure in hometown regions. A well-known example is Mexico's '3-for-1 program', a model for the much-touted publicprivate partnership initiatives in development policy (PPP). Each \$1 of remittances from hometown associations in government approved development projects receives an additional $\$ 1$ in matching funds each from federal, state, and local governments. Other examples relate to tourism from immigrant communities to the 'old country', constituting a major earner for countries from Ireland to Vietnam. Clearly, as with family remittances, hometown associations privilege certain places, and it would be far-fetched to see this as transnational social policy addressing inequalities within the countries of origin. Nonetheless, hometown associations contribute to processes such as 'opportunity hoarding' (Tilly, 1998), that is, categories of persons - in this case migrants-occupying a niche which advances their well-being. For example, Croatian migrants concentrating in the restaurant business in Toronto may be well placed not only to incorporate new immigrants from the homeland into this economic sector in the niche they control, in giving them employment and later on providing support for them to open up their own business, but also to send remittances back home through the same support structures.

The response of states to their diasporas abroad in general, and to hometown associations in particular, has evolved in the course of migration processes. For instance, Morocco started with repression and the surveillance of migrants in countries such as France from the 1960s to the 1980s. Starting in the 1990s it moved to 'courting the diaspora' (de Haas, 2006). Such developments can also be observed in the case of Mexico, Haiti, the Dominican Republic, and their emigrants in the US. Mexico, for example, has made efforts in recent years to increase support of emigrants abroad by delivering services through consular institutions. There is a wide array of instruments in countries such as Mexico. Such measures encompass the Paisano Programme, consular registrations (matricula), and the Institute of Mexicans Abroad, to efforts to institutionalise dual citizenship and political rights, such as dual nationality (1996) and the possibility of extraterritorial voting in national elections (2005). Such programmes are likely to stimulate and promote transnational associations.

Yet there are also potential conflicts between hometown associations and communities of origin, which clearly go beyond mere divergence of interests and pose more fundamental dilemmas. Transnational organisations and groups are able to join, exit and voice, and do so through geographical mobility and strengthening transnational ties. While the complementarity of exit and voice may be applauded from a normative point of view, such as the increased empowerment it thus provides for those who are mobile, the transnationalisation of political participation creates tensions between mobile and relatively immobile people and associations. There is a 
basic dilemma arising out of the democratic principle that those who take decisions should also be part of those affected by them. On the one hand, transnational migrants may be participating in decision-making in the regions of origin. On the other hand, when it comes to the consequences of decisions, they act as third parties. This fundamental dilemma is particularly striking in transformation countries, such as Mexico, which have built up an infrastructure reaching out to emigrants abroad. On the local level in particular, however, such transnational forms are not insignificant because, quite often, substantial parts of the so-called community of origin are residing (temporarily) abroad (cf. Waldinger et al., 2006). The problem is not quite as pernicious on the national level because usually a much lower percentage of the overall population is engaged in transnational migration. The dominant pattern of transnational migration is that there are few migrants from most places and many from a few places (locales), taking states as the broader unit of analysis. In essence, transnational ties enhance the combination of exit and voice on a sustained basis and therefore contribute to the unequal chances for exercising political rights. It may thus impact on trust between citizens and affect the readiness of focused and diffuse solidarity.

The transfer of resources other than remittances may also challenge understandings of the 'good life' or, to put it more technically, development concepts, in places of migrant origin and return. In some cases, the 'feminisation of migration' resulted in the very transformation of gender relations, which constituted the backbone of the migratory arrangements in small and large kinship groups. In Bangladesh, the migration of women to Malaysia led to changes in social practices. Malaysia is considered a role model for Bangladesh, and is also a Muslim country. Once the flow of women from Bangladesh to Malaysia had started, young women sought to emigrate, resulting in increased economic independence. Those engaging in migration gave loans to other women and also participated in the labour force in Bangladesh. Since female labour-force participation in Malaysia is relatively high, migrant and even non-migrant women adopted some of the same practices in Bangladesh (Dannecker, 2004). Yet, we also know of other cases in which transnational practices exacerbated gendered power

Copyright (c) 2007 John Wiley \& Sons, Ltd. structures, especially when control over financial remittances rested with men (Mahler and Pessar, 2001, on El Salvador; see also Walton-Roberts, 2004). These examples suggest that transnational groups should not be regarded simply as unitary actors in all respects, but rather as social collectives connected by sometimes conflicting social and symbolic ties.

\section{Networks of Businesspersons: Ensuring the Return Flow of Financial Capital}

Networks of business persons from emigration states who live and may have settled abroad may constitute an important source of financial transfer and investment, both as immigrant entrepreneurs in their new societies of settlement and, if involved with countries of origin, as transnational entrepreneurs. More and more emigration country governments have started programmes to attract investments by emigrants. By far the largest set of transnational networks in the world - a set of interlinked local, national and regional networks - is the so-called Overseas Chinese. Nowadays, the Overseas Chinese can promote trade by providing market information and matching and referral services because they use - among other resources - co-ethnic reciprocal ties to keep knowledge of network members' characteristics fresh.

There is a widespread belief that business networks are a vestigial or at least culture-bound phenomenon that is withering away with modernisation. This assumption is debatable since business groups are ubiquitous in the developed countries of continental Europe. Numerous statistical and case studies provide evidence that transnational business networks promote international trade by alleviating problems of contract enforcement and providing information about trading opportunities (Rauch, 2001: 1180, 1200). Historically, business networks created and upheld crucial resources for its functioning by reverting to social mechanisms ensuring trust based on reciprocity as a moral resource. Two mechanisms mattered above all: moral community and collective punishment. Firstly, trade in most parts of the world until the nineteenth century rested on a moral community, to be observed amongst Northern European networks of the Hanse, the Hausas in Africa, and the Overseas Chinese in southeast Asia. Among ethnic 
groups, it was sometimes group endogamy facilitated by the separate identity the diaspora minority maintained within the host society. Secondly, transaction costs are lowered by collective punishment of transgressors by all merchants and thus deterred opportunistic behaviour in transnational transactions. In modern times, there is evidence that new telecommunications technology is a complement to, rather than a substitute for, face-to-face contact; it appears that information is still an 'experience good' and that face-to-face contact still helps to build the trust needed to close deals.

Emigrants and the children of emigrants living abroad are sometimes seen by the governments in the country of origin, many of whom have established ministries in recent years dealing with emigrants and expatriates overseas, as effective middlemen who play a crucial role in brokering foreign investments or investing themselves. And in development economics it is also a common assumption that development defined as economic growth does not depend primarily on the inflow of financial capital, but on entrepreneurial spirit (Hirschman, 1958). Businesspersons as communities of practice may foster an atmosphere in which an entrepreneurial spirit conducive to economic success may prosper. Cases at hand are emigrants from Taiwan and India. Overseas Indians who settled in Silicon Valley in the US, for example, contributed to the rise of the region around Bangalore as the hub of the Indian industry in information technology. Indian emigrants who worked as highly skilled specialists in Silicon Valley invested in the burgeoning Indian IT industry. Earlier, software specialists in India were already employed by overseas companies to process data and develop programs (Leclerc and Meyer, 2007). The Indian investors from Silicon Valley added another dimension in setting up companies in India. Other multinational companies from the US and Europe followed suit (Cornelius et al., 2001). The Taiwanese experience parallels this case (Tseng, 2000).

In these cases, because of a large and welleducated tertiary sector of citizens living abroad, the potential for foreign investment has been high. Again, about 20 million citizens from India live abroad, a group second in size only to that of the Chinese population abroad. It is estimated that the income of this category amounts to more than a third of India's GDP. It is therefore no surprise that this category, called 'non-resident Indians' (NRI), provided about $10 \%$ of foreign direct investment (FDI) in India and a sizable part of its venture capital. The People's Republic of China may serve as a case par excellence: about $50 \%$ of FDI comes from some 30 million Overseas Chinese. Successive Chinese governments have created incentives for capital investment by Overseas Chinese in selected enterprise areas (Saxenian, 2002). Undoubtedly, global production chains, in this case software development and processing, have made investments like these more feasible and more profitable.

Yet we know very little about the networks and cliques that business persons entertain among each other and with bridging brokers in the emigration country. We need to know more about how business persons act as brokers, as communities in between, sometimes called 'transnational workers' or 'temporary returnees' who work in emigration and immigration regions and play a role as middlemen linking businesses in the two regions with their personal networks and technological and market know-how. It seems plausible to assume that quite a few emigrants investing in their countries of origin have insider advantages, such as knowledge of the language and local customs, and are likely to enjoy the trust of bureaucrats who administer economic planning.

At times transnational social formations of business persons concatenate into social formations such as hometown associations: for example, transnational ties forged by Chinese entrepreneurs in southeast Asia in Chinese Voluntary Associations (shetuan) reaching back into ancestral home towns. There is no clear-cut membership, and such Chinese Voluntary Associations are not so well defined and neatly bounded as their European or North American counterparts. Rather, these associations focus on the relationships that bind members into a common identity and that form a moral community out of which a sense of duty and obligation arises. As a structural form, shetuans have fulfilled various changing functions, among them as regional trading networks. Since the principal rationale for shetu$a n^{\prime}$ 's transnational activities lies in seizing expanding business opportunities worldwide, their built-in commercial functions can easily be adapted to promote the new agendas. Unlike the shetuan's pre-1980 practices which primarily 
exercised influence through personal and informal links, the current wave of transnational activities is marked by a significant degree of institutionalisation: sophisticated agencies systematically carry out transnational missions, and specific ideological justifications legitimise and sustain this new pattern (Hong, 1998: 590).

Governments have implemented a host of policies both to attract highly skilled emigrants from abroad as returnees, and to entice those who stay overseas to maintain productive links. For example, the Indian government offers tax incentives for emigrants, and tries to use their expertise, advice and ideas to equip Indian companies, and to create opportunities for overseas Indian companies. One symbolic but highly visible instrument has been a special resident status for emigrant businesspersons, akin to dual citizenship. This status has created added entry options for privileged groups.

This example already hints at potential conflicts of interest between emigrant groups and states of origin. The Chinese state, for instance, encourages cross-border flows of financial capital but certainly objects to the import of political ideas via emigrants. Emigrants' ideas concerning liberalisation of the political regime and a greater recognition of human rights and democratic ideals have not been welcome, albeit the groups involved in the transfer of economic versus political capital are not one and the same: students vs. business persons. Moreover, as in the Chinese case, the separation of Taiwan and the People's Republic makes for uneasy relations between business persons from Taiwan investing in mainland China on the one hand, and the government of the People's Republic. In order to circumvent such problems, quite a few Taiwanese business persons active in mainland China therefore acquire dual citizenship and act under labels such as American or British (Tseng, 2000).

The thorny issue of the selectivity effects of development via transnationalisation is here even more obvious than in cases of migrant worker remittances. States and economic elites join to sponsor investments, perhaps to the detriment of certain sectors of education and the economy. The Indian government, for example, has heavily sponsored advanced institutes of learning, the Indian Institutes of Technology (IIT). No such concerted effort can be discerned when it comes to basic education. Certainly, in

Copyright (c) 2007 John Wiley \& Sons, Ltd. this case the federal and provincial states have created the preconditions necessary for the communities of business persons to offer services and investment. Such a coalition of states and communities of business persons in planning and implementing foreign direct investments makes it far-fetched to consider such processes as 'bottom up' development (Bhagwati, 2003).

For immigration countries, immigrant or ethnic entrepreneurship may be part of beneficial transnational business ties. Canadian-based studies have shown that a doubling of skilled migration from Asia saw a 74\% increase in Asian imports in Canada (Page and Adams, 2004). Ethnic entrepreneurship may also be instrumental in creating jobs for immigrants and natives. Markets may expand in two directions. Firstly, nostalgia among immigrants for the foods and products of the country of origin creates markets for those products in the immigration country, fostering local production and international trade - such as among Turkish immigrants in Germany. Secondly, migrant entrepreneurs may invest in the countries of origin and thus contribute directly to economic development abroad. The transnational version of migrant entrepreneurship is a prime example of financial capital following persons, or more precisely, capital accumulated by those persons first attracted abroad by capital. In all these processes, social capital as reciprocity is a crucial bridging mechanism.

\section{Epistemic Networks: Exchanging Knowledge}

Epistemic groups of scholars and experts are exemplary instances of transnational social formations in social spaces without geographical propinquity. Scientists and professional experts share common models, theories, and sometimes even lifestyles characterised by high geographical mobility. The flow of ideas is ensured by reciprocity as exchange and reciprocity as a social norm. Recently, major political actors such as international organisations and state governments have started to focus on not only the emigration, re-migration or return of highly skilled professionals, but also on the formation of transnational networks. This shift of perspective is partly a result of the fact that while many of those categorised as highly skilled do not return to the regions of origin, they nonetheless form bordercrossing epistemic networks and associations, 
which also sometimes extend into the countries of origin. For example, half of all foreign students who earn doctorates in the US are still in that country five years later. The flip side is a massive outflow from emigration regions: according to the World Bank, Africa, for example, lost a third of its executives over the past 40 to 50 years (Black and King, 2004). In short, the role of knowledge exchange for economic growth and development has regained importance over recent years. Indeed, academic and policy actors nowadays discuss resource transfers across countries within the framework of the knowledge society (Stehr, 1992; Scott, 2004). There are numerous claims about the importance of knowledge transfer and scientific cooperation for development (World Bank, 1999). In connection with public policies, there have been increased efforts to connect migration policies to research policies in the developing states, transformation states, and industrial countries (BMZ, 2001: 12; Pacheco, 2003; House of Commons, 2004). In essence, as in other cases, state actors try to tap or even capture transnational flows and the accompanying social mechanisms for domestic, economic and, in this case, above all scientific development.

It is noteworthy that academic analysis of the developmental consequences of the mobility of highly skilled persons has paralleled political expectations held by states and international organisations. In the 1960s, a majority of analyses entertained the idea of a 'brain gain' for developing countries, and mobility was seen as a resource for modernising developing countries (Ladame, 1970). In the 1970s and 1980s, the reverse was held to be true, that is, the more critical view of the 'brain drain' carried the day, with the underlying assumption that emigration was harmful to developing countries. This is not surprising because such studies situated the phenomenon within the dependency literature paradigm. In the course of the 1990s, the dominant academic and political mood shifted again. Experts and politicians from industrial countries in need of highly-skilled technological specialists now increasingly assert that there is a 'brain circulation', an apparently neutral term. There are claims about mutual benefits for all actors involved, for the highly skilled as well as for the origin and destination countries themselves, such as the creation of jobs in the software industry and increasing capital investment from abroad.
In highly industrialised countries, public policies directed towards recruiting highly skilled migrants now routinely also include efforts to attract international students. Subsequently, some OECD countries such as Germany have recently changed their legislation to allow international students to remain or to re-enter, once they have completed their studies (Kuptsch, 2006). At the same time, countries of emigration have begun to take initiatives to reverse the 'brain drain'. Examples include the Indian government's efforts to sponsor investments by citizens abroad in the Information Technology (IT) sector.

There are various possible outcomes of brain transfer, among them: (1) brain drain followed by brain gain; (2) brain drain; (3) a global brain chain; and (4) brain waste. In the first case, brain drain followed by brain gain, there is usually deficit at exit, followed by possible gains not only for migrants and immigration countries but also for countries of origin. The emigration of the highly skilled may be advantageous for those remaining in the country of origin, when educated people leave and report back that they have been economically successful. Such communication creates an incentive to those left behind to improve their knowledge and social capital, for example, by investing in higher education. Such processes may happen on a large scale, but only a small percentage of those whose capital assets have improved will actually leave, while the rest will stay in the country of origin and benefit from improved education in the home country (Stark and Wang, 2001). In the case of brain drain, there is no replacement capability, an outcome that seems to affect the poorest countries especially. Prominent empirical examples include the socalled (health) 'care drain' from Zambia, Liberia and Zimbabwe. Nurses and medical doctors from these and other countries of sub-Saharan Africa fill the gaps in the health systems of developed countries, although the deficits in their countries of origin are very large, not least because of the AIDS/HIV pandemic in southern Africa. Meanwhile, healthcare systems in OECD countries reap the benefits. The third possibility is a global brain chain or 'staged cascade' which may involve both brain drain and brain gain. A noteworthy example is medical doctors who move from Canada to the US, who are in turn replaced by South Africans in Canada. At the far 
end of the chain, physicians from sub-Saharan countries relocate to South Africa. Another possibility associated with the mobility of the highly skilled is 'brain waste', that is, professionals who are employed as domestics in immigration countries (e.g. Filipino nurses in Gulf states in the household sector), or highly skilled workers who return to their country of origin but cannot find employment at their skill level, such as natural scientists who do not have access to appropriate laboratories. The worst case scenario is called 'brain desertification'. In this case the highly skilled do not return and do not sustain any ties with those who stayed in the countries of origin.

For developing and some transformation countries, the volume of skills involved is sizeable. What constitutes a small proportion of personnel in the North is a large one for the South. For instance, about a third of researchers and engineers originating in developing countries are employed in OECD countries. Generally, transformation countries, such as the People's Republic of China, have greater leverage and may succeed in re-attracting their intellectuals. Also, proportionately fewer and fewer Chinese students go abroad to study. Overall, there is mounting evidence that some epistemic groups of scholars and experts also reach back into countries of origin (Meyer and Charum, 1995).

In immigration countries, notions of economic globalisation have led to an increased effort by companies and states to attract post-secondary international students and future scientists. OECD countries have thus changed their legislation, moving from a 'red card' to a 'red carpet' strategy. The hunt for knowledge workers is nonetheless reminiscent of 'body shopping' and the poaching of workers, a well-known strategy employed by many countries emulating the success of economic leaders, such as eighteenthcentury England attracting workers from the Netherlands (Chang, 2002: 18). The difference is, however, that nowadays it is not the countries catching up that engage in poaching, but those who are furthest ahead. The US is currently the only country with a positive balance vis-à-vis all the other countries in the world at the same time. Persons of foreign origin make up $12 \%$ of the entire highly qualified segment of the US labour market. Nonetheless, this share is similar in other OECD countries (Kuptsch, 2006). Thus, while in simple numbers the contribution of the developing world to the developed is relatively marginal, it is nevertheless strategically important since it eases shortages in the labour market in the target countries.

Interestingly, there are clear limits to state sponsorship and hierarchical control of epistemic networks. In 2003, there were roughly 40 such networks documented throughout the world, involving about 35 developing countries. These networks concern activities such as joint research projects, information exchange, technology transfers, joint ventures, or training sessions. Many of these epistemic communities are based on the idea that the 'return option' is not the only alternative to a skills exodus. For them, there is an alternative transnational or 'diaspora option' (Barré et al., 2003). Not only nation-state governments but also international organisations are engaged in setting up such networks, as reflected in, for example, policy programmes like the United Nations Development Program's 'Transfer of Knowledge through Expatriate Nationals' (TOKTEN). The policy involves the production of databases of skilled nationals overseas who may be willing to engage in particular development projects. Another example is the International Organization of Migration's (IOM) 'Migration for Development in Africa' (MIDA) programme, which seeks to mobilise the skills of African citizens abroad for the benefit of Africa's development. Yet emigration of the highly skilled can be beneficial only if there is already a stock of highly qualified people (Lowell et al., 2004). Also, for the disaspora option to succeed, there needs to be an attractive infrastructure in place in the countries of origin.

While systems of training and research are predominantly organised along national state lines, epistemic networks often evade the narrow principles of the 'national interest'. This is an example of how transnational networks constitute social formations suigeneris, which lead an autonomous life. An important case in point is the network Red Caldas, set up by the Colombian government in the early 1990s (Chaparro et al., 2006). This experience suggests the importance of specialised research communities, built along decentralised networks, which have a genuinely transnational orientation. In the first phase, the government set up centralised radial networks, which developed later into epistemic 
communities with a decentralised character. In this stage the project developed along national state nodes from the early to mid-1990s. The government established national nodes in all countries around the globe which had a critical mass of Colombian graduate students and researchers - all in all 27 countries and 874 researchers and graduate students were involved. Working groups formed which brought together researchers in Colombia, Colombian researchers in the various countries abroad, and researchers from developed countries who were interested in these topics. Red Caldas maintained a registry of such projects. In the second half of the 1990s it turned out that both researchers based in Colombia and those abroad did not congregate so much around the national nodes but congealed in specialised epistemic networks, concatenating along disciplinary and interdisciplinary lines. Eventually, Red Caldas evolved into a 'network of networks' when support from the centre, namely the national government, diminished. The national nodes practically disappeared in the late 1990s. The epistemic networks in which researchers associated with Colombia actually participated had a more clearly defined membership and defined activities, and were characterised by a more participatory rather than hierarchical model. In sum, the state-centric effort to establish transnational epistemic networks along national lines failed, while decentralised networks succeeded in attracting natural and social scientists.

Epistemic networks and the associated flows of knowledge are an excellent example of the different principles upon which non-state associations and states can base collective action. Epistemic networks and associations provide club goods, as distinct from private goods and public goods. While public goods and thus the common good provided by states are in an ideal way characterised by the twin principles of nonexcludability and access for all, or non-exclusiveness, private goods are at the opposite end. Club goods are in between, in that non-members can actually be excluded. However, based on membership in associations or access to networks, the goods provided are indeed collective (Breuer et al., 1995). Put briefly, it is the boundaries between members and non-members or those with access and those without that matter most in the provision of club goods. In the case of transnational epistemic formations, knowledge is akin to a club good, situated in between knowledge as a public and a private good. On the one hand, the increasing flows of knowledge across borders, helped by the rapid dissemination and adoption of information and communication technologies, suggest that knowledge, an essential value for development, can be considered a public good. On the other hand, knowledge is a private good, reflected in the importance of intellectual property rights (IPRs) and other forms of knowledge appropriation. Obviously, the production of and access to knowledge is selective. Also, transnational epistemic networks and associations provide mechanisms for the translation of science into knowledge as a factor of production and decision-making. Certain forms of knowledge are generated through social formations of like-minded people or peers who work in a given field or on a given topic. Epistemic networks are also connected to extension workers and end-users, the so-called stakeholders. In short, epistemic networks are organisational forms for producing and accessing 'protected knowledge' that circulates freely only within these social formations, and is accessible only to members.

This finding on club goods could have important implications for other sectors as well, such as hometown associations, business persons and political diasporas. The benefits of knowledge, financial and social remittances are not simply public goods on a global, national or local scale. It is above all certain categories of persons and associations to whom the benefits accrue. Most benefits are typical instances of club goods from which outsiders may be excluded. In order to understand outcomes of transnational flows, it is essential to identify the mechanisms by which resources are transferred across state borders.

\section{Diasporas as Ethno-national Communities: Political Ideas and Interests}

Social remittances such as concepts of democracy, gender equity and human rights, but also claims towards national self-determination waged by diaspora groups, constitute the most visible threat to the interests of states. The claims coming from ethno-national groups are a particularly disputed phenomenon. Three categories 
of transnational groups in particular pose three degrees of potential challenge to the so-called homeland or country of origin or country of emigration: refugees and exiles, stateless diasporas, and state-based diasporas. The role of all three categories clearly goes far beyond the flow of financial capital, such as financing rebel armies (Collier and Hoeffler, 2000), and concerns the definition of interests and identities of political communities. States are not only based upon organisational infrastructure and various mechanisms of legitimate rule-making and rule implementation, but also on common elements of identity which underpin political communities such as nations. And membership in such communities is not only based on formal ties between states and citizens, but also amongst the citizens themselves (Faist, 2001). Such ties amongst citizens anonymous to each other - and thus constituting a sort of diffuse solidarity - constitute the informal basis for trust in political systems such as democracies, and cannot simply be created by states in a top-down process. Refugees, émigrés and members of stateless diasporas often conceive of themselves as the vanguard of a new nation-state, or a nation-state to be reformed or revolutionised. At first sight they seem to be challengers or even competitors of existing (emigration) states. The transfer of politico-cultural capital takes various forms, ranging from the activities of exiles aimed at the improvement of human rights in their countries of origin, to longdistance nationalism which strives to form a new nation-state. Long distance nationalism, in particular, can be traced back to the early days of the nation-state. One of its critics, Lord Acton, called diasporas 'the nursery of nationality' (cited in Hockenos, 2003: 262). Prominent examples include the role played by refugee and exile communities that have fuelled conflicts in the countries of origin from abroad, such as Kosovo Albanians, the Mujahedin in the case of Iran, or Chechen freedom fighters. A high degree of politico-cultural coherence can be found among 'stateless' diasporas whose declared intention is the founding of a new nation-state or at least achieving a high degree of autonomy in the declared homeland. Such communities are represented by organisations or liberation movements which are in clear conflict with the former homeland, as the cases of some Kurdish and Tamil communities attest (Van Hear, 2003).
Yet refugees and exiles have often had significant impact on political development, by mediating between competing groups or providing resources for reconciliation and reconstruction. Prominent examples include the South African diaspora's role in the anti-apartheid movement and the more recent engagement of the Ugandan and Nigerian diasporas. In these cases, the rhetoric which accompanied political mobilisation around transnational efforts has been good governance and rule of law, the implementation of human rights, and democratisation (Zunzer, 2004). Much less attention has been paid to the potential role of migrants and their children to resolve conflict in the country of origin (Von Carlowitz, 2004).

'State-based' and established diasporas, such as the Armenian, Chinese and Palestianian diasporas in the US and Europe, are considered by the homeland as strategic assets, as in the Chinese government's view of highly skilled Overseas Chinese. The notion that homeland and diaspora constitute one people is especially strong for relatively weak, new or reconstituted states, in conflicts with other states or groups (e.g. Armenian-Azeri; Shain, 2002). One may argue that national diasporas who participate in the foreign affairs of a country of settlement move from being disenfranchised groups to one with an entry ticket into mainstream society and politics (Shain, 1999, on US foreign policy). Yet strong diasporas and fledgling home states produce a complex set-up of international and transnational politics which go beyond the notion of 'two-level games' (Putnam, 1988). The concept of two-level games considers both domestic political constituencies and the counterpart's minimum demands. Intervention by strong diasporas implies an extension into a three-level game, especially in conflict perpetuation and resolution. Moreover, established diasporas may play a crucial role in the definition of what are called national interest and national identity, both of which are best seen as flexible, rather than static, constructs. Interests of the diaspora and the home state may significantly diverge, and are not a unified whole. Forms of transnational identity may connect both homeland and host country. There are instances of transnational identities of a nationalist kind, as in the case of Poland and Ireland and their diasporas in the US which formed in the nineteenth and the first part of the 
twentieth centuries. In exceptional cases, some interpretations of the transnational identity may be detached from a national identity and thus compete with statist transnationalism, as in the idea of a Jewish diaspora not centred on the state of Israel but in a global diaspora (Boyarin, 1994).

All of this suggests that a transnational perspective on national interests and national identities can support, compete with, or even challenge the congruence of a people, territory, and authority in a state. One of the challenges goes beyond this trinity. If transnational communities conceive of themselves as diasporas connected to a nation-building project, such as Kosovar Albanians in the late 1990s, they usually portray themselves as ethnically homogenous entities; in short, a Volk based more on common cultural heritage than subjective predispositions of citizens toward a state and a constitution. There is an inherent tension between the concept of state usually advocated by nationalist diasporas according to which the members constitute a Volk, on the one hand, and a democratic concept which sees the political community made up of all its varied citizens, on the other hand.

\section{OUTLOOK: TRANSNATIONAL SOCIAL SPACES AND MIGRATION CONTROL}

This analysis has followed the emergence of migrant actors in development in both discursive and institutional dimensions. The discursive analysis has traced the history of ideas of how community and civil society, often used interchangeably, have been conceptualised by development institutions, pointing out the interactions with other principles of social order, especially market and state. The debate on the role of migrants in general, and migrant associations in particular, has been part of a more general trend in development discourses. It has been pointed out that migrant collective actors have come to occupy a prominent role in the legitimation of the current round of enthusiasm on the migrationdevelopment nexus. The new enthusiasm on migration and development overlooks the tensions between migrants as transnational development agents on the one hand, and states of origin and destination on the other hand.

Two issues need to be considered in further research: firstly, the reconstruction of transnational groups, associations, networks and organisations, which goes far beyond the issues relevant for migration and development; and secondly, how states open and restrict transnational social spaces for development(s) indirectly through migration control. The former helps to avoid essentialising of transnational subjects and to counter the tendency of both academic research and policy-making to reconstruct transnational collective subjects as unitary actors. The latter focus is necessary to clarify the changing role of states. More attention needs to be paid to how states structure transnational social spaces, for example, through the regulation of transnational migration.

The empirical examples discussed here suggest that transnational collectives, such as groups, associations, organisations and diasporas, cannot be treated as unitary actors if one wants to understand the tensions inherent in transnational spaces and the implications for the conceptualisation of transnationalisation. Certainly, the opportunities for transnational actors have changed in the process of globalisation, and not only for migrant-based collectives (Evans, 2000). Because of the apparent increase in interconnectedness through long-distance communication, facilitated face-to-face communication and interaction through travel, the diffusion of ideas and knowledge, economic, cultural and political life across the borders of states has become more dense and extensive. The spaces 'in between' states have multiplied. Some of the cherished concepts of migration research need to be questioned because they may not be adequate to capture more fluid lifestyles, modes of action and collective behaviour. The lives of migrants are not necessarily characterised by one-time settlement and commitment to one society or associations and groups in one society. Therefore, dichotomous distinctions such as 'origin' vs. 'destination' and 'emigration' vs. 'immigration' no longer hold, if only because many traditional emigration countries have become both transit and immigration countries, Turkey being a typical example. Less obviously, other dichotomies such as 'temporary vs. permanent' or 'labour migrant vs. refugee' also no longer hold if the goal is to map trajectories of mobile populations. One first step has been a renewed interest in the notion of social space. This has implied, among other things, the need to conceptualise migration 
beyond its demographic construction as 'flows' and 'stocks' of people, and to look at the 'in between places'. This train of rethinking should not stop at other important notions such as citizenship. Clearly, transnational social spaces do not necessarily imply that communities of origin and communities of destination are congruent in terms of interests and ideas. As mentioned above, geographically mobile persons who do not permanently reside in the community of origin may hold very different notions of development from those 'at home'. This problem of incongruence has not been paid sufficient attention in terms of its conceptual implications. For example, notions such as transnational citizenship are used to describe political participation, rights, duties, and belonging of transnational migrants through mechanisms such as hometown associations. But an important element of citizenship is equal political freedom, the principle of democracy - a principle which holds that those taking decisions (voice) should not be able to exit at will. While we may still want to use the term citizenship in a transnational context, we should strive to avoid the ecological fallacy of simply transposing concepts from the nation-state level to transnational social spaces.

As to the second venue for further research, the concept of the national state or nation-state is critical to defining the opportunity structures in transnational social spaces and transactions connected to development. States having significant numbers of emigrants living abroad have tried to capture the benefits of transnational spaces by devising new institutions, such as ministries for the diasporas and a host of ways to court their citizens abroad. Yet one also needs to pay attention to more indirect means for state efforts to control transnational social spaces. One such instrument is migration control. For a start, there is a clear contradiction between the emphasis on the potential of migrant remittances for development, on the one hand, and growing immigration restrictions for the majority of potential migrants from South to North. Yet, paradoxically, restrictive migration policies may be conducive to financial remittances and transnational kinship groups. Contemporary international borders are much more akin to sieves than to medieval brick walls. Their principal function is to protect the integrity of the socio-economic, political and cultural cohesion of the population which lies behind them. One important measure is to filter unacceptable or illegitimate migrants and to welcome those which increase the competitiveness of the economy. To paraphrase Aristide Zolberg, the hewers of wood and the drawers of water are implicitly 'wanted but not welcome' (Zolberg, 1987). By contrast, those regarded as highly skilled migrants who transmit knowledge and foreign investments are not only wanted but also quite welcome. Their case is very infrequently used to connect migration to socio-cultural cohesion. The migration-development link is usually mentioned in its function to reduce the propensities for migration to Europe. Coupled with such controls are policies making development aid to states in the European periphery conditional upon their willingness to control undocumented migration (Faist and Ette, 2007). In other words, emigration countries need to show their willingness to control illegal migration to immigration countries in order to get development aid. A good example for such conditionality is Morocco, which partly depends on the EU for financial contributions. The EU is thus outsourcing its border controls. Yet these policies, provided they are half-way effective, may produce unintended consequences. For example, the implicit migration policy logic of remittance and development discussions is that migrants should keep migrating, in a rather restrictive migration control configuration that sets migrants up to remit while family members are left behind. This is so because restrictive immigration policy towards some categories of mobility, especially towards illegal ones, produces ruptured transnational families. Then remittances may become even more relevant. Seen from a functional point of view, the public policies that differ towards undocumented migrants and the highly skilled, restrictive in the former and welcoming in the latter case, are important for sustaining the same kind of effect, namely the circulation of persons and other resources - thus contributing to the further transnationalisation of life worlds and to the increasing relevance of remittances.

Ultimately, the migration-development nexus is linked to both migration control and the incorporation of migrants. From most Northern states' point of view, there is the task of separating wanted and welcome migrants from (economically) wanted but (socially and culturally) unwelcome migrants. Migration officially welcomed, 
such as those of highly-skilled professionals, is usually cast as part and parcel of a desirable process of globalisation and the almost inescapable competitions for the 'best brains' from all over the world. However, at the same time, those fulfilling crucial tasks in labour markets but who are not necessarily welcome, especially workers in the service economy, agriculture, but also asylum-seekers, are often portrayed as constituting a threat to national security, cultural homogeneity and social cohesion in the North. In order to legitimate migration controls, which separate wanted from unwelcome migrants, policymakers introduce schemes for migration control, nowadays often called 'migration management', which suggest that the benefits of migration can be maximised at least economically for the immigration states in attracting the highly skilled and keeping out the migrants who allegedly do not contribute to the welfare of immigration states. In this way, migration and development are linked to the incorporation and social integration of migrants, or more precisely, the social integration of national societies. There are two dimensions concerning the link between migration controls on the one hand and the migrationdevelopment nexus on the other hand. Firstly, there is the legitimation of policies in OECD states, and secondly, actual cooperation between North and South. The connection of migration control with development cooperation is one way of increasing legitimacy for stricter controls because it alludes to mutual benefits for all actors involved in North and South, East and West: the highly skilled are free to circulate and everybody else may - in the long run - stay in their home country. Moreover, in order to increase alreadyfunctioning border and internal controls in OECD countries to even higher levels, the cooperation of the governments of states of origin and transit with OECD countries has to be ensured. This will only materialise if the new task for emigration countries in the South, in extraterritorial or forward migration control for immigration countries, also gives advantages for them. In this way migration control, incorporation in immigration countries, and development cooperation between North and South, West and East are inextricably intertwined. Regarding the legitimation of migration control in the South and in the North, strengthening the migration-development nexus is indeed an ingenuous instrument.

\section{NOTES}

(1) The focus here is on transnational ties arising out of South-North migration and not South-South migration. But note that fully $40 \%$ of transnational migrants move between so-called developing countries. Also, this paper deals with transnational and not with domestic migrants within states, although the latter may be much more numerous. To compare: there were about 175 million transnational migrants in the early twenty-first century. By contrast, India alone has 200 million internal migrants, and China has 120 million. In Vietnam, there were about 4.5 million internal migrants from 1994-99, in contrast to 300,000 who went abroad during the same period. Among the poorest persons, migration takes place primarily within and between developing countries. For example, many countries in south-east Asia heavily rely on cheap migrant labour from neighbouring countries, e.g. Indonesian workers in Malaysia. As to refugees, two-thirds live in developing countries and more than a third dwell in the least-developed countries. Nonetheless, over the past decades, the proportion of transnational migrants vis-à-vis domestic migrants has increased (United Nations, 2004).

(2) The regional distribution pattern looks as follows: Latin America and the Caribbean receive the most remittances ( $\$ 30$ bio), followed by South Asia (\$18 bio), East Asia and the Pacific ( $\$ 18$ bio), the Middle East and North Africa (\$13 bio), and Europe and Central Asia (\$10 bio). Sub-Saharan Africa, including the poorest countries in the world, receives the smallest amount ( $\$ 4$ bio). In Latin America, remittances amount to $2 \%$ of the GDP. Yet in smaller economies the proportion is much higher: $29 \%$ of GNP in Haiti; in El Salvador, Honduras, and the Dominican Republic, about $15 \%$ of GDP (Orozco, 2002).

(3) If one was precise one should use the term 'transstate' instead of 'transnational'. The former term indicates that the point of departure is not relations and spaces in between nations but in between states and across states. Here, the term transnational is used because the distinction between nation and state is not empirically central. There is a lot of stimulating literature which discusses 'transnational social fields' (Basch et al., 1994), 'transnational social formations' (Smith and Guarnizo, 1998) and 'transnational social spaces' (Faist, 2004). For a discussion of transnational approaches in population geography, see Smith and Bailey (2004).

(4) Social capital can be understood in two ways: (1) social ties can be resources available to persons 
(Bourdieu, 1983); and (2) social capital constitutes resources, such as reciprocity and solidarity, which are available to groups and thus enable cooperation (Putnam, 1993).

(5) If one were to liberalise transnational migration, migration would increase under a global system of free trade for all factors of production, including labour, because of factor price equalisation, that is, the tendency of wages to equalise as workers move from poorer to richer regions of the world. According to neo-classical theory, this would mean that trade and migration are substitutes: countries that have relatively cheaper labour export labour-intensive goods or workers. Over time, differences in the prices of goods and the wages of workers should be reduced with freer trade (e.g. Fischer et al., 1997). One of the by-products would be a significant drop in the wage level and probably welfare state provision in highly industrialised immigration countries.

(6) Of course, labour circulation and temporary migration should be distinguished analytically, if only because temporary migrants may turn into permanent ones, as evident in the 'guestworker' experience in the 1960s. Circulation differs in that the idea of residence and all concomitant conflicts around migrants as socio-cultural and political agents are not part of the consideration.

(7) Not all transnational migrants or mobile persons develop dense and continuous transnational ties. Some of them really cut their roots, such as most ethnic Germans from Eastern Europe who migrated in the late twentieth century. Another problem of transnational research has been overaggregation. Migrants as actors across borders are mainly conceptualised in research and public discourse as 'diasporas'. This term tends to treat migrants from a given emigration state as a whole, e.g. the Indian diaspora or the Chinese diaspora. This is problematic in three ways. Firstly, it implies a one-sided relationship in focusing only on the country of origin. This dovetails with the traditional definitions of diaspora which implies forced dispersal, and does not open our eyes to two-way relationships. Secondly, a religious or national diaspora group may not capture self-understanding. For example, not all migrants from Turkey consider themselves Turks; some would selfidentity as Kurds. Thirdly, there are different levels of aggregation: families, villages, regions, nations, and cross-cutting allegiances, such as religions. One needs to unpack the notion of diaspora and make room for different types of transnational social formations. Here, the term is reserved for self-ascribed large national political communities.
(8) It is notoriously unclear what hometown associations exactly are. The older German term Landsmannschaften, which was used to denote similar phenomena about 150 years ago, seems to capture better what is meant: migrant associations with some sort of regional focus regarding the origin of immigrants.

\section{REFERENCES}

Barré P, Hernandez V, Meyer J-P, Vinck D (eds). 2003. Diasporas scientifiques. Expertise collégiale. Institut de Recherche sur le Développement. Ministère des Affaires Etrangères: Paris.

Basch L, Glick-Schiller N, Blanc C. 1994. Nations Unbound: Transnational Projects, Postcolonial Predicaments, and Deterritorialized Nation-States. Gordon and Breach: Langhorne, PA.

Bates RH (ed.). 1988. Toward a Political Economy of Development: A Rational Choice Perspective. University of California Press: Berkeley, CA.

Bhagwati J. 2003. Borders beyond control. Foreign Affairs 82: 98-105.

Black R, King R. 2004. Editorial introduction: Migration, return and development in West Africa. Population, Space and Place 10: 75-83.

Bourdieu P. 1983. Ökonomisches Kapital, kulturelles Kapital, soziales Kapital. Soziale Welt, Special Issue on Social Inequalities, R. Kreckel (ed.): 183-198.

Boyarin J. 1994. Remapping Memory: The Politics of Timespace. University of Minnesota Press: Minneapolis.

Breuer M, Faist T, Jordan B. 1995. Collective action, migration and welfare states. International Sociology 10: 369-386.

Brubaker R. 2005. The 'diaspora' diaspora. Ethnic and Racial Studies 28: 1-19.

Bundesministerium für Wirtschaftliche Zusammenarbeit und Entwicklung (BMZ). 2001. Wissenschaftsförderung, Hochschulkooperation und Migrationspolitik in der Entwicklungszusammenarbeit: Neue Herausforderungen und Schwerpunkte. Stellungnahme des Wissenschaftlichen Beirats beim BMZ, No. 035. Bonn: BMZ.

Chang H-J. 2002. Kicking Away the Ladder. Development Strategy in Historical Perspective. Anthem Press: London.

Chang H-J, Grabel I. 2004. Reclaiming Development: an Alternative Economic Policy Manual. University Press: Dhaka.

Chaparro F, Hernán J, Quintero V. 2006. Promise and frustration of diaspora networks: lessons from the network of Colombian researchers abroad. In Diaspora Networks and the International Migration of Skills: How Countries Can Draw on Their Talent Abroad, Kuznetsov Y (ed.). World Bank: Washington, DC; 187-198. 
Clarke N. 2004. Mobility, fixity, and agency: Australia's working holiday programme. Population, Space and Place 10: 411-420.

Collier P, Hoeffler A. 2000. Greed and Grievance in Civil War. Policy Research Working Papers, World Bank: Washington, DC.

Cornelius WA, Espenshade TJ, Salehyan I (eds). 2001. The International Migration of the Highly Skilled: Demand, Supply, and Development Consequences in Sending and Receiving Countries. Center for Comparative Immigration Studies, University of California, San Diego: La Jolla, CA.

Dannecker P. 2004. Transnational migration and the transformation of gender relations: the case of Bangladeshi labour migrants. Current Sociology 53: 655-674.

De Haan A. 2006. Migration in the Development Studies Literature: Has It Come Out of Its Marginality? United Nations University, UNU-WIDER, World Institute for Development Economics Research, Research Paper No. 2006/19: Helsinki.

De Haas H. 2006. Engaging Diasporas. How governments and development agencies can support diaspora involvement in the development of origin countries. A study for Oxfam Novib, Oxford: International Migration Institute, James Martin 21st Century School, University of Oxford.

Delgado WR, Covarrubias HM. 2005. The Reshaping of Mexican Labour Exports under NAFTA: Paradoxes and Challenges. Program in Development Studies, Autonomous University of Zacatecas: Zacatecas.

Diamond L. 1996. Is the third wave over? Journal of Democracy 7: 20-37.

Escobar A. 1995. Encountering Development: The Making and Unmaking of the Third World. Princeton University Press: Princeton, NJ.

European Commission. 2005. Migration and Development: Some Concrete Orientations. COM (2005) 390 final of 1 September 2005. Brussels.

Evans P. 1996. Government action, social capital and development: creating synergy across the public private divide, Special section. World Development 26: 1033-1132.

Evans P. 2000. Fighting marginalization with transnational networks: counter-hegemonic globalization. Contemporary Sociology 29: 230-241.

Faist T. 2000. The Volume and Dynamics of International Migration and Transnational Social Spaces. Oxford University Press: Oxford.

Faist T. 2001. Social citizenship in the European Union: nested membership. Journal of Common Market Studies 39: 39-60.

Faist T. 2004. Social space. In Encyclopedia of Social Theory, Vol. 2, Ritzer G (ed.). Sage: Beverly Hills, CA; 760-763.

Faist T, Ette A (eds). 2007. The Europeanization of National Immigration Policies: Between the European
Union and National Autonomy. Palgrave Macmillan: Houndmills, UK.

Faist T, Kivisto P (eds). 2007. Dual Citizenship in a Global Perspective: From Unitary to Multiple Citizenship. Palgrave Macmillan: Houndmills, UK.

Findlay A. 2003. Skilled transients: the invisible phenomenon? In The Cambridge Survey of World Migration, Cohen R (ed.). Cambridge University Press: Cambridge; 515-523.

Fischer PA, Martin R, Straubhaar T. 1997. Should I stay or should I go? International Migration, Immobility and Development: Multidisciplinary Perspectives, Hammar T, Brochmann G, Tamas K, Faist T (eds). Berg: Oxford; 49-90.

Global Commission on International Migration (GCIM). 2005. Migration in an Interconnected World: New Directions for Action. Report of the Global Commission on International Migration. United Nations: New York.

Goldring L. 2002. The Mexican state and transmigrant organizations: negotiating the boundaries of membership and participation. Latin American Research Review 17: 55-99.

Hamilton B, Whaley J. 1984. Efficiency and distributional implications of global restrictions on labour mobility. Journal of Development Economics 14: 6175.

Hirschman A. 1958. The Strategy of Economic Development. Yale University Press: New Haven, CT.

Hirschman A. 1970. Exit, Voice, and Loyalty. Harvard University Press: Cambridge, MA.

Hockenos P. 2003. Homeland Calling: Exile, Patriotism and the Balkan Wars. Cornell University Press: Ithaca, NY.

Hong L. 1998. Old linkages, new networks: the globalization of Overseas Chinese voluntary associations and its implications. China Quarterly 155: 582-609.

House of Commons, International Development Committee. 2004. Migration and Development: How to Make Migration Work for Poverty Reduction. Sixth Report of Session 2003-04. The Stationary Office Limited: London.

Huntington S. 1966. Political Order in Changing Societies. Yale University Press: New Haven, CT.

International Organisation of Migration (IOM). 2005. World Migration 2005: Costs and Benefits of International Migration. IOM: Geneva.

Kapur D. 2004. Remittances: The New Development Mantra? G-24 Discussion Paper Series, No. 29. Washington, DC: The World Bank.

Kindleberger CP. 1967. Europe's Postwar Growth: the Role of Labour Supply. Harvard University Press: Cambridge, MA.

Kuptsch C. 2006. Students and talent flow - the case of Europe: From castle to harbour? In Competing for Global Talent, Kuptsch C, Fong PE (eds). 
International Institute for Labour Studies (IILS), International Labour Office (ILO): Geneva; and Wee Kim Wee Centre, Singapore Management University: Singapore; 33-61.

Kuznetsov Y (ed.). 2006. Diaspora Networks and the International Migration of Skills: How Countries Can Draw on Their Talent Abroad. World Bank: Washington, DC.

Lacroix T. 2003. Les réseaux marocains d'aide au développement. Hommes \& Migrations 1242: 121128.

Ladame PA. 1970. Contestée: La circulation des élites. International Migration Review 2: 39-49.

Leclerc E, Meyer J-B. 2007. Knowledge diasporas and development: a shrinking space for skepticism. Asian Population Studies 3: 153-168.

Levitt P, Nyberg-Sørensen N. 2004. The Transnational Turn in Migration Studies. Global Commission on International Migration (GCIM), Global Migration Perspectives, No. 6: Geneva.

Lewis AW. 1954. Theory of Economic Growth. Unwin: London.

Lowell LB, Findlay A, Stewart E. 2004. Brain Strain. Optimising highly skilled migration from developing countries. Asylum and Migration Working Paper 3, Institute for Public Policy Research: London.

Mahler SJ, Pessar PR. 2001. Gendered geographies of power: analyzing gender across transnational spaces. Identities: Gobal Studies in Culture and Power 7: 441459.

Maimbo SM, Ratha D (eds). 2005. Remittances: Development Impact and Future Prospects. World Bank: Washington, DC.

Martin PL. 1991. The Unfinished Story: Turkish Labour Migration in Western Europe, with Special Reference to the Federal Republic of Germany. International Labour Office (ILO): Geneva.

McMichael P. 1996. Development and Social Change. Pine Forge: Thousand Oaks, CA.

Merz BJ, Chen LC, Geithner PF (eds). 2007. Diasporas and Development. Global Equity Initiative, Asia Center, Harvard University. Harvard University Press: Cambridge, MA.

Meyer J-B, Charum J. 1995. La 'fuite des cerveaux' estelle épuisée? Cahiers des Sciences Humaines 31: 10031017.

Moja JC. 2005. Immigrants and associations: a global and historical perspective. Journal of Ethnic and Migration Studies 31: 833-864.

North DC. 1990. Institutional Change and Economic Performance. Cambridge University Press: Cambridge.

Nyíri P. 2001. Expatriating is patriotic? The discourse on 'new migrants' in the People's Republic of China and identity construction among recent migrants from the PRC. Journal of Ethnic and Migration Studies 27: 635-654.
Orozco M. 2002. Attracting Remittances: Market, Money and Reduced Costs. Report commissioned by the Multilateral Investment Fund of the Inter-American Development Bank: Washington, DC.

Pacheco MK. 2003. El Codesarrollo en España: Posiblidades y Desafíos. Migraciones 13/2003: 185207.

Page J, Adams R. 2004. The Impact of International Migration and Remittances on Poverty. World Bank: Washington, DC.

Portes A, Walton J. 1981. Labour, Class, and the International System. Academic Books: New York.

Putnam RD. 1988. Diplomatic and domestic politics: the logic of two-level games. International Organisation 41: 427-461.

Putnam RD. 1993. Making Democracy Work: Civic Traditions in Modern Italy. Princeton University Press: Princeton.

Rauch J. 2001. Business and social networks in international trade. Journal of Economic Literature 34: 1177-1204.

Saxenian AL. 2002. The Silicon Valley connection: transnational networks and regional development in Taiwan, China and India. Science, Technology and Society 7: 117-132.

Scott S. 2004. Transnational exchange amongst skilled British migrants in Paris. Population, Space and Place 10: 391-410.

Shain Y. 1999. Marketing the American Creed Abroad. Cambridge University Press: Cambridge.

Shain Y. 2002. The role of diasporas in conflict perpetuation or resolution. SAIS Review 22: 115-144.

Shain Y, Barth A. 2003. Diasporas and international relations theory. International Organization 57: 449479.

Smith DP, Bailey AJ. 2004. Editorial introduction: Linking transnational migrants and transnationalism, Population, Space and Place 10: 357-360.

Smith MP, Guarnizo LE (eds). 1998. Transnationalism from Below. Transaction Publishers: New Brunswick.

Stark O, Wang Y. 2001. Inducing Human Capital Formation: Migration as a Substitute for Subsidies. Economics Series No. 100. Institute for Advanced Studies: Vienna.

Stehr N. 1992. The Culture and Power of Knowledge: Inquiries into Contemporary Societies. de Gruyter: Berlin.

Streeck W, Schmitter PC. 1985. Community, market, state - and associations? The prospective contribution of interest governance to social order. European Sociological Review 1: 119-138.

Thomas WI, Znaniecki F. 1927 [1918-1921]. The Polish Peasant in Europe and America, 5 vols. Alfred A. Knopf: New York.

Tilly C. 1998. Durable Inequality. University of California Press: Berkeley, CA. 
Tseng Y-F. 2000. The mobility of entrepreneurs and capital: Taiwanese capital-linked migration. International Migration 38: 143-166.

United Nations. 2004. World Economic and Social Survey, Part II International Migration. Department of Economic and Social Affairs. New York: United Nations.

Van Hear N. 2003. Refugee diasporas, remittances, development, and conflict. Migration Information Source, June 1. Migration Policy Institute: Washington, DC.

Von Carlowitz L. 2004. Migranten als Garanten? Über die Schwierigkeiten beim Rechtsstaatsexport in Nachkriegsgesellschaften. HSFK Standpunkte No. 6/2004. Hessische Stiftung für Friedens- und Konfliktforschung: Frankfurt.

Waldinger R, Popkin E, Magana HA. 2006. Conflict and Contestation in the Cross-Border Community: Hometown Associations Revisited. University of California, Los Angeles, Department of Sociology, Paper 11. Available at: http://repositories.cdlib.org/ uclasoc/11.

Wallerstein I. 1974. The Modern World System: Capitalist Agriculture and the Origins of the European
World-Economy in the Sixteenth Century. Academic Press: New York.

Walton-Roberts M. 2004. Transnational migration theory in population geography: gendered practices in networks linking Canada and India. Population, Space and Place 10: 361-373.

World Bank. 1999. World Development Report 1998-99: Knowledge for Development. Oxford University Press: New York.

Zolberg AR. 1987. 'Wanted but not welcome': alien labor in Western development. In Population in an Interacting World, Alonso W (ed.). Harvard University Press: Cambridge, MA; 36-73.

Zunzer W. 2004. Diaspora Communities and Civil Conflict Transformation / Diasporagemeinschaften und zivile Konflikttransformation. Berghof Stiftung: Berlin.

Zweig D. 2006. Learning to compete: China's efforts to encourage a 'reverse brain drain'. In Competing for Global Talent, Kuptsch C, Fong PE (eds). International Institute for Labour Studies (IILS), International Labour Office (ILO): Geneva; and Wee Kim Wee Centre, Singapore Management University: Singapore; 187-214. 